\title{
The Influence of Drying Process Conditions on the Physical Properties, Bioactive Compounds and Stability of Encapsulated Pumpkin Seed Oil
}

\author{
Dorota Ogrodowska $^{1} \cdot$ Malgorzata Tańska $^{1} \cdot$ Waldemar Brandt $^{2}$
}

Received: 17 February 2016/Accepted: 2 March 2017 / Published online: 22 March 2017

(C) The Author(s) 2017. This article is published with open access at Springerlink.com

\begin{abstract}
In this study, the influence of encapsulation process conditions on the physical properties and chemical composition of encapsulated pumpkin seed oil was investigated. Four variants of encapsulated oil were prepared: spray-dried nonhomogenized emulsions at the inlet temperatures of 180 and $130{ }^{\circ} \mathrm{C}$, spray-dried homogenized emulsion at the inlet temperature of $130{ }^{\circ} \mathrm{C}$, and freeze-dried homogenized emulsion. The emulsion was prepared by mixing $10.6 \%$ oil with $19.8 \%$ wall materials ( $15.9 \%$ maltodextrin $+0.5 \%$ guar gum $+3.9 \%$ whey protein concentrate) and $69.6 \%$ distilled water. The quality of encapsulated pumpkin seed oil was evaluated by encapsulation efficiency, surface oil, total oil and moisture contents, flowing properties, color, and size. Additionally, fatty acid composition, pigment characteristics, and the content of bioactive compounds (tocopherols, squalene, and sterols) were determined. Changes of these components after the encapsulation process in comparison to the control pumpkin seed oil were considered as stability parameters. The highest encapsulation efficiency was obtained by spray-drying at the inlet temperature of $130{ }^{\circ} \mathrm{C}$. Generally, the spray-drying process had a positive effect upon the physical parameters of encapsulated pumpkin seed oil but results were dependent on process conditions. The higher inlet temperature generated more surface oil, but capsules obtained at the lower
\end{abstract}

Małgorzata Tańska

m.tanska@uwm.edu.pl

1 Chair of Plant Material Processing and Chemistry, Faculty of Food Science, University of Warmia and Mazury, Plac Cieszyński 1, 10-718 Olsztyn, Poland

2 Department of Dairy Science and Quality Management, Faculty of Food Science, University of Warmia and Mazury, Michała Oczapowskiego 7, Olsztyn 10-719, Poland temperature were greater in size and more deformed. Although freeze-drying proceeded at a very low temperature, the powder obtained with this technique was characterized by the highest bioactive compound losses (with the exception of sterols) and the lowest stability. The homogenization process applied before spray-drying affected greater polyunsaturated fatty acid, squalene, and pigment degradation. In conclusion, results of the study showed that the spray-drying non-homogenized emulsion was a more recommendable technique for the encapsulation of pumpkin seed oil because of smaller changes of native compounds and better oxidative stability.

Keywords Pumpkin seed oil · Encapsulation · Spray-drying · Freeze-drying $\cdot$ Bioactive compounds $\cdot$ Physical properties

\section{Introduction}

Pumpkin seeds have interesting organoleptic properties and are a rich source of bioactive substances. According to Vujasinovic et al. (2010), hulled seeds contain about $38 \%$ of fat, and naked seeds $44 \%$ of fat. The intense color of pumpkin seed oil is attributed to its high content of carotenoids and chlorophylls. For example, carotenoid content of pumpkin seed oil produced by supercritical fluid extraction is at about $13.6 \mathrm{mg} / 100 \mathrm{~g}$ of oil, of which $\beta$-carotene accounted for about $55 \%$. Other carotenoids are $\alpha$-carotene $(36.1 \%)$, lutein (4.5\%), and cryptoxanthin (1.0\%) (Durante et al. 2014). Oil extracted from the seeds of different pumpkin species and from different growing regions significantly differs in terms of bioactive compound content. They may contain $647-$ $971 \mathrm{mg} / \mathrm{kg}$ tocopherols (Fruhwirth et al. 2003), 718 $898 \mathrm{mg} / 100 \mathrm{~g}$ sterols (Rabrenović et al. 2014), and 529$788 \mathrm{mg} / 100 \mathrm{~g}$ squalene (Gorjanović et al. 2011). Apart from non-lipid bioactive components, the value of pumpkin seed oil 
is enhanced by a nutritionally beneficial composition of fatty acids. The predominant fatty acid is linoleic acid, which accounts for 42.0 to $59.2 \%$ of total fatty acids (NawirskaOlszańska et al. 2013).

The incorporation of typical bioactive compounds into different food matrices is limited by their inherent characteristics, such as taste and incompatibility with the formulation and its ingredients, and subsequent processing that can affect the retention of labile compounds. In this respect, encapsulation is a universal technology capable to meet these needs, thus contributing to the development of high-value functional foods (Celli et al. 2015).

Encapsulation is a technique used for coating or encapsulating one or more materials inside another material. Common techniques applied for the industrial encapsulation of oils include spray-drying, fluidized bed coating, extrusion, freezedrying, and coacervation phase separation (Drusch and Mannino 2009).

The spray-drying technique for encapsulation of different oils have been frequently reviewed over the last decade, e.g., olive oil (Sun-Waterhouse et al. 2011), flaxseed oil (Quispe-Condori et al. 2011), sage oil (Rodea-González et al. 2012), soya bean oil (Jones et al. 2013), fish oil (Aghbashlo et al. 2013; Pourashouri et al. 2014), and chia oil (Ixtaina et al. 2015). Both wall material selection and emulsion properties affect the process efficiency and the product stability (Pourashouri et al. 2014). Some of the most common wall materials used for oil encapsulation by spray-drying include gelatin, carbohydrates (maltodextrin, starch, inulin), proteins (milk, whey, plants), and plant gums (Arabic, guar). However, combination of wall materials is often used to improve the emulsifying properties and increase the efficiency of encapsulation (Calvo et al. 2012; Pourashouri et al. 2014). Spray-drying encapsulation is an optimal solution for oils because it allows for the transformation of emulsion into powder in a very short period of time, simultaneously preserving its valuable properties (Westergaard 2004).

Unlike spray-drying, freeze-drying has been shown to be an attractive method for extending the shelf life of foods. Freeze-drying is a process in which water is frozen, followed by its removal from the sample, initially by sublimation (primary drying at low shelf temperature and a moderate vacuum) and then by desorption (secondary drying, is facilitated by raising shelf temperature and reducing chamber pressure to a minimum) (Celli et al. 2015). This method can minimize product damage likely to occur as a consequence of high drying temperature used in spray-drying. Freeze-drying was used for the encapsulation of cardamom oil (Najafi et al. 2011), flaxseed oil (Liu et al. 2010; Karaca et al. 2013), walnut oil (Calvo et al. 2011), and fish oil (Anwar and Kunz 2011) and of functional ingredients like $\beta$-carotene (Spada et al. 2012).

Encapsulated bioactive compounds of oils can be applied in food products such as yoghurt (Wang et al. 2011), milkshake (Barrow et al. 2009), spaghetti (Iafelice et al.
2008), fermented sausage (Josquin et al. 2012), salt (Zimmermann et al. 2004), and cheese (Banville et al. 2000).

The encapsulation of oil is in the focus of interest of food industries, and results of this study will provide information that would enable producing good-quality encapsulated pumpkin seed oil. The objectives of the present study were to investigate the influence of encapsulation process conditions (spray-drying at different temperatures and freeze-drying) and emulsion pretreatment before spray-drying on the characteristics of powders and losses of bioactive compounds and oil stability.

\section{Materials and Methods}

\section{Material}

A commercial 100\% cold-pressed pumpkin seed oil was used in the study (purchased from Szarłat, Łomża, Poland). Maltodextrin (DE 14-22) and guar gum were purchased from EDPOL Food \& Innovation, Łomża, Poland. Whey protein concentrate (WPC 80) was purchased from Ostrowia, Ostrów Mazowiecka, Poland.

\section{Encapsulation Process}

The first stage of oil encapsulation involved the formation of a fine and stable emulsion of the core material (pumpkin seed oil) in the wall material solution. Concentrations of core and wall materials in emulsion are listed in Table 1. The composition of wall materials (maltodextrin, whey protein concentrate, and guar gum) was adapted from Carneiro et al. (2013) and Karaca et al. (2013). Final proportion of wall compounds was established on the base of preliminary results. The pumpkin seed oil was blended with an aqueous solution of maltodextrin, guar gum, and protein concentrate using Thermomix equipment (Vorwerk, Germany) operated at $9000 \mathrm{rpm}$ for $120 \mathrm{~s}$ at $40{ }^{\circ} \mathrm{C}$. The resultant emulsion was then dried or additionally homogenized before drying at 240 bar (first step) and 40 bar (second step) using a high-pressure laboratory valve homogenizer (Panda 2K, GEA Niro Soavi, Parma, Italy).

A pilot-plant spray-dryer (A/S Niro Atomizer, Denmark; spraying mechanism-disc) was used to convert the emulsions into encapsulated powder. The emulsion was pumped into a spray-dryer chamber. The drying parameters during the process were controlled to keep $180^{\circ} \mathrm{C}(\mathrm{EPO}-1)$ and $130{ }^{\circ} \mathrm{C}$ (EPO-2 and EPO-3) inlet temperatures and $90{ }^{\circ} \mathrm{C}$ outlet temperature. The feed flow rate was $133 \mathrm{~mL} / \mathrm{min}(\mathrm{EPO}-1)$ and $77 \mathrm{~mL} / \mathrm{min}$ (EPO-2 and EPO-3).

The sample EPO-4 was prepared by including the emulsion into aluminum pans and frozen at $-20{ }^{\circ} \mathrm{C}$ for $24 \mathrm{~h}$ and then freeze-drying using a lyophilizer (New Brunswick, USA). During the freeze-drying process, the product temperature 
Table 1 Emulsion characteristics and encapsulation process conditions

\begin{tabular}{|c|c|c|c|c|c|c|c|c|}
\hline \multirow[t]{2}{*}{$\begin{array}{l}\text { Combination code of } \\
\text { powders }\end{array}$} & \multirow[t]{2}{*}{$\begin{array}{l}\text { Production } \\
\text { method }\end{array}$} & \multirow[t]{2}{*}{$\begin{array}{l}\text { Production } \\
\text { parameters }\left({ }^{\circ} \mathrm{C}\right)\end{array}$} & \multirow[t]{2}{*}{$\begin{array}{l}\text { Homogenization of emulsion } \\
\text { before drying }\end{array}$} & \multirow[t]{2}{*}{$\begin{array}{l}\text { Emulsion } \\
\mathrm{pH}\end{array}$} & \multicolumn{3}{|c|}{$\begin{array}{l}\text { Matrix } \\
\text { combination (\%) }\end{array}$} & \multirow[t]{2}{*}{$\begin{array}{l}\text { Pumpkin seed } \\
\text { oil }(\%)\end{array}$} \\
\hline & & & & & MD & WPC & GG & \\
\hline EPO-1 & $\mathrm{SD}$ & $180 / 90^{\mathrm{a}}$ & No & 6.15 & 15.4 & 3.9 & 0.5 & 10.6 \\
\hline EPO-2 & $\mathrm{SD}$ & $130 / 90^{\mathrm{a}}$ & No & 6.22 & 15.4 & 3.9 & 0.5 & 10.6 \\
\hline EPO-3 & $\mathrm{SD}$ & $130 / 90^{\mathrm{a}}$ & Yes & 6.16 & 15.4 & 3.9 & 0.5 & 10.6 \\
\hline EPO-4 & FD & $-56 / 18^{b}$ & Yes & 6.17 & 15.4 & 3.9 & 0.5 & 10.6 \\
\hline
\end{tabular}

$S D$ spray-drying, $F D$ freeze-drying, $M D$ maltodextrin, $W P C 80$ whey protein concentrate, $G G$ guar gum

${ }^{\text {a } I n l e t / o u t l e t ~ t e m p e r a t u r e s ~}$

${ }^{\mathrm{b}}$ First/secondary drying temperatures

raised from an initial value of $-50{ }^{\circ} \mathrm{C}$ to a final temperature of $18^{\circ} \mathrm{C}$. Freeze-drying was performed at a pressure of $0.12 \mathrm{mbar}$ and drying time reaching $72 \mathrm{~h}$. After the freeze-drying process, the sample was grinded by using a glass rod to transform it to powder form.

\section{Basic Parameters of Pumpkin Seed Oil Powders}

The content of surface oil (content of non-encapsulated oil in pumpkin seed oil powder) was determined by the washing method described by Liu et al. (2010) with modification. Hexane $(50 \mathrm{~mL})$ was added to $5 \mathrm{~g}$ of powder in a $250-\mathrm{mL}$ flask, and the sample was shaken for $5 \mathrm{~min}$. The slurry was then filtered through a filter paper, and each filter paper with solid particles was washed three times with $20 \mathrm{~mL}$ of hexane. The filtrate caught into a $250-\mathrm{mL}$ round-bottom flask was then mounted in the rotary evaporator (Büchi Labortechnik AG, Switzerland) to evaporate hexane under an $\mathrm{N}_{2}$ stream. The residue was weighted, and the content of surface oil was expressed as percentage of powder $(n=3)$.
The total content of encapsulated oil was determined after the extraction with a $2: 1(v / v)$ chloroform/methanol mixture performed according to the modified method described by Folch et al. (1957). The powder was weighed into a Falcon centrifuge tube, then $20 \mathrm{~mL}$ of a chloroform/methanol mixture was added to the tube and the whole sample was ultrasonicated for $10 \mathrm{~min}$. Afterwards, the sample was shaken for $20 \mathrm{~min}$. The mixture was then centrifuged, and the solid phase was re-extracted two times more with the same volume of the extractant. The liquid phases were combined in a separatory funnel. Fifteen milliliters of $0.58 \%$ sodium chloride was added, and the mixture was gently shaken. After phase separation, the chloroform phase was dried with anhydrous sodium sulfate and filtered again. Finally, the extract was evaporated to dryness in the rotary evaporator (Büchi Labortechnik AG) under an $\mathrm{N}_{2}$ stream. The residue was weighted, and the total content of encapsulated oil was expressed as percentage of powder $(n=3)$.

The encapsulation efficiency (EE) was calculated as follows:

$\mathrm{EE}=[($ Total oil content - Non-encapsulated oil content $) /$ Total oil content $] \times 100 \%$

The moisture content of powder was measured according to the AOAC Method (1995).

The bulk density (BD) of powder, denoting the weight of a defined volume of powder $\left(1 \mathrm{~m}^{3}\right)$ in its natural state with no compaction, was expressed in kilograms per cubic meter $(n=4)$. It was measured by the standard method using a $61-$ 400 apparent density tester (Coesfeld Materialtest, Dortmund, Germany).

The wettability (W) of powder $(n=4)$ was measured according to the method reported by Westergaard (2004), while the solubility index (SI) of powder $(n=4)$ was measured according to the method described by Sharma et al. (2012).

\section{Color of Pumpkin Seed Oil Powder}

The color of encapsulated oil was measured using digital image analysis (DIA) according to the method described by Tańska et al. (2005). The images were acquired by a highresolution, low-noise charge-coupled device (CCD) Nikon DXM-1200 color camera (Nikon Inc., Melville, USA) and analyzed by Laboratory Universal Computer Image Analysis (LUCIA) G v. 4.8 software. The frame grabber was at a resolution of $1280 \times 1024$ pixels. The same amount of samples $(n=10)$ were examined from a distance (lens to object) of $13 \mathrm{~cm}$. The light source was a Kaiser RB-5004- 
HF High Frequency Daylight Copy Light Set with $4 \times 36 \mathrm{~W}$ fluorescent light tubes (color temperature about $5400 \mathrm{~K}$ ) (Kaiser Fototechnik GmbH \& Co. KG, Germany). The results were expressed in the CIEL*a*b* color space, where $\mathrm{L} *$ is the lightness, $\mathrm{a}^{*}$ is the greenness-redness, and $\mathrm{b}^{*}$ is the bluenessyellowness. The $\mathrm{L}^{*}$ component was in the range of $0-100 \%$, while $\mathrm{a}^{*}$ and $\mathrm{b} *$ components were in the range from -120 to +120 . Before analysis, the calibration to a standard white reflective plate was done.

\section{Particle Size Distribution and Morphology of Pumpkin Seed Oil Powders}

Particle size distribution, and De Broucker D(4,3) and Sauter $\mathrm{D}(3,2)$ mean diameters of capsules (EPO-1, EPO-2, EPO-3) were measured by laser light dispersion using a Mastersizer 3000 (Malvern Mastersizer X, Malvern, UK). Powder samples were placed into a measuring cell till obscuration has been achieved at $0.1-50 \%$. On the basis of the volume share distribution $(n=4)$, a granulometric composition was determined using the characteristic parameters $\mathrm{D}_{10}, \mathrm{D}_{50}$, and $\mathrm{D}_{90}$, which are the equivalent volume diameters at 10, 50, and $90 \%$ cumulative volumes, respectively.

Scanning electron microscopy was applied to investigate the morphology of the powders. The images were obtained by a SEM Quanta 200 (FEI Company, Hillsboro, OR). The samples were placed on double-sided adhesive carbon tabs, mounted on SEM tubs, and coated with palladium in a sputter coater. The coated samples were then analyzed using the SEM operating an accelerating voltage of $30 \mathrm{kV}$ with $\times 20, \times 50$, $\times 100, \times 200, \times 400$, and $\times 800$ magnifications.

Microstructural analysis of the encapsulated oil was also conducted using a Nikon Eclipse reversed confocal microscope (Nikon, Tokyo, Japan) with an oil immersion objective at magnification of $\times 60$. Oil capsules were stained by suspending them in 50\% glycerol $(v / v)$ containing Sudan solution $(2 \%$ in ethanol, $w / v)$.

\section{Fatty Acid Composition of Native and Encapsulated Pumpkin Seed Oils}

Fatty acid composition was determined according to the method described by Zadernowski and Sosulski (1978) with some modifications. The oil sample (native and extracted from powder by chloroform/methanol, 2:1, v/v) was dissolved in chloroform-methanol-sulfuric acid (100:100:1, v/v/v), transferred into vials, and sealed hermetically over a gas burner. The fatty acids methylation was carried out by heating the mixture at $70{ }^{\circ} \mathrm{C}$ for $2 \mathrm{~h}$. After cooling, the powdered zinc was added to the mixture. The obtained methyl esters were dried in a stream of nitrogen, re-dissolved in hexane, and centrifuged. The analysis was carried out with the method of gas chromatography using a GCMS-QP2010 Plus system
(Shimadzu, Japan). Fatty acid separation was performed on a BPX70 capillary column $(25 \mathrm{~m} \times 0.22 \mathrm{~mm} \times 0.25 \mu \mathrm{m}$; SGE Analytical Science, Victoria, Australia). Helium was used as the carrier gas at a flow rate of $0.9 \mathrm{~mL} / \mathrm{min}$. The temperatures were set as follows: interface of GC-MS $240{ }^{\circ} \mathrm{C}$ and the ion source $240{ }^{\circ} \mathrm{C}$; the electron energy was $70 \mathrm{eV}$. Column temperature was programmed in the range from 150 to $250{ }^{\circ} \mathrm{C}$. The results were expressed as percentage of each fatty acid in total fatty acids $(n=3)$.

\section{Content of Bioactive Compounds in Native and Encapsulated Pumpkin Seed Oils}

The content of sterols and squalene was determined by GC coupled with MS (GC-MS) according to the method described by Roszkowska et al. (2015). The oil sample (native and extracted from powder by chloroform/methanol, 2:1, $v / v$ ) was dissolved in hexane, and a $5 \alpha$-cholestane solution was added as an internal standard. Then, the mixture was saponified by adding $2 \mathrm{M} \mathrm{KOH}$ solution in methanol at $70{ }^{\circ} \mathrm{C}$ for $30 \mathrm{~min}$. Sterols and squalene were extracted with diethyl ether. The dry extract was re-dissolved in pyridine and $\mathrm{N}, \mathrm{O}$ bis(trimethylsilyl)trifluoroacetamide (BSTFA) with $1 \%$ trimethylchlorosilane (TMCS), and derivatization was conducted at $60{ }^{\circ} \mathrm{C}$ for $60 \mathrm{~min}$. The mixture was re-dissolved in heptane and analyzed using the GCMS-QP2010 Plus system (Shimadzu, Kyoto, Japan). Separation of sterols and squalene was performed on a ZB-5 ms capillary column $(30 \mathrm{~m} \times 0.25 \mathrm{~mm} \times 0.25 \mu \mathrm{m}$; Phenomenex, Torrance, CA, USA). Helium was used as a carrier gas at a flow rate of $0.9 \mathrm{~mL} / \mathrm{min}$. The temperatures were as follows: injector $230{ }^{\circ} \mathrm{C}$, the column in the range from 70 to $310^{\circ} \mathrm{C}$, the interface of GC-MS $240{ }^{\circ} \mathrm{C}$, and the ion source $220^{\circ} \mathrm{C}$; the electron energy was $70 \mathrm{eV}$. The content of sterols and squalene was calculated based on the internal standard method and expressed per $100 \mathrm{~g}$ of oil $(n=3)$.

The content of tocopherols was determined by HPLC, according to the method described by Czaplicki et al. (2011). The sample of native oil was diluted in hexane and subsequently centrifuged $(10,000 \mathrm{rpm}$ for $10 \mathrm{~min})$ in a $5417 \mathrm{R}$ type Eppendorf centrifuge (Eppendorf AG, Hamburg, Germany). The encapsulated oil was extracted three times with hexane, and collected extracts were centrifuged (10,000 rpm for $10 \mathrm{~min})$ in a 5417R-type Eppendorf centrifuge. The analysis was carried out using an Agilent Technologies 1200 RP-HPLC apparatus with a fluorescence detector (Santa Clara, CA, USA). Separation was performed on a LiChrospher Si 60 column $(250 \mathrm{~mm} \times 4 \mathrm{~mm} \times 5 \mu \mathrm{m}$; Merck, Darmstadt, Germany). The mobile phase was $0.7 \%$ isopropanol in a hexane solution, and flow rate was at $1 \mathrm{~mL} /$ min. The fluorescence detector was set at excitation and emission wavelengths of 296 and $330 \mathrm{~nm}$, respectively. The 
content of tocopherols was calculated based on the external calibration curves and expressed per $100 \mathrm{~g}$ of oil $(n=3)$.

\section{Pigment Characteristics of Native and Encapsulated Pumpkin Seed Oils}

The composition of pigments in native and extracted (by chloroform/methanol, 2:1, v/v) from encapsulated pumpkin seed oils was determined with the spectrophotometric method. The absorption of chlorophylls (at $668 \mathrm{~nm}$ ) and carotenoids (at $442 \mathrm{~nm})$ in oil dissolved in hexane $(1: 1, v / v$ and $1: 10, v / v$, respectively) was measured $(n=3)$ using a FLUOstar Omega multimode microplate reader (BMG LABTECH, Offenburg, Germany). The total color (TC) of oil was calculated according to Polish Standard (PN-A-86934:1995P) (1995) as follows:

$\mathrm{TC}=1000 \times($ absorption of chlorophylls + absorption of carotenoids $)$

\section{Oxidative Stability of Native and Encapsulated Pumpkin Seed Oils}

A 743 Rancimat (Metrohm, Switzerland) eight-channel oxidative stability instrument was used to evaluate the oxidative stability of the native and encapsulated (extracted from powder by chloroform/methanol, 2:1, v/v) pumpkin seed oils. Briefly, $2.5 \mathrm{~g}$ of the oil sample was weighed into a reaction vessel. The capped vessel was placed in a thermostated electric heating block. The temperature was set at $110^{\circ} \mathrm{C}$, and an air flow rate of $20 \mathrm{~L} / \mathrm{h}$ was applied. The oxidative stability index (OSI) was expressed in hours $(n=4)$. Induction time of oils was tested on a Rancimat apparatus 743 (Metrohm, Herisau, Switzerland).

\section{Statistical Analysis}

The obtained results were analyzed statistically using Statistica 12.0 PL software (StatSoft, Kraków, Poland). The differences between the samples were determined using the analysis of variance (ANOVA) with Duncan test at $p \leq 0.05$ significance level.

\section{Results and Discussion}

\section{Basic Parameters of Pumpkin Seed Oil Powders}

The characteristics of physicochemical properties of the powders are reported in Table 2. Results showed that the powder prepared by freeze-drying had a lower total oil content (31\%) when compared to those prepared by spray-drying, with values at $31.9 \%$ (EPO-1), 32.2\% (EPO-2), and $34.8 \%$ (EPO-3).

Encapsulation efficiency (EE) reflects the real amount of oil that is encapsulated inside the matrix. The highest EE (74\%) was obtained by spray-drying (EPO-2) where the inlet temperature was at $130{ }^{\circ} \mathrm{C}$. The $\mathrm{EE}$ values were the same (69\%) for the samples obtained by SD (EPO-1) and FD (EPO-4) but lower than those determined for the other samples. The statistical analysis indicated that the EE differed significantly $(p<0.05)$ within the same drying method (SD).

In this study, surface oil content differed significantly and was the lowest (8.2\%) in the EPO-2 sample. The content of surface fat for other samples ranged from 9.2\% (EPO-4) to 9.7\% (EPO-1). Pourashouri et al. (2014) investigated the effect of wall material, including fish gelatin $(\mathrm{Ge})$, chitosan $(\mathrm{Cs})$ with maltodextrin (MD) alone, or their combination and also the effect of microbial transglutaminase (MTGase) addition to gelatin, on the physicochemical properties of cod liver oil powder obtained by spray-drying. In their study, the encapsulation efficiency determined for the multilayer emulsion system varied from the minimum value of $67.35 \%$ to the maximum value of $88.0 \%$, whereas surface oil content ranged from $2.26 \%$ in the Ge-MD treatment to $5.2 \%$ in the Cs-MD-based powders. Experimental results reported by Karaca et al. (2013) showed that powders of flaxseed oil prepared by freeze-drying with maltodextrin type $\mathrm{DE}$ (dextrin equivalent) 9 had a lower surface oil content $(6.5 \%)$ compared to those prepared with maltodextrin type DE 18 (8.3\%). The authors explained that the lower surface oil content observed in the sample prepared with DE 9 could be due to the orientation of the higher molecular weight glucose oligomers towards the entrapped oil resulting in a more hydrophilic capsule surface structure. This oligomer orientation could result in the adsorption of less flaxseed oil at the capsule surface when compared to DE 18 (more hydrolyzed product). Quispe-Condori et al. (2011) analyzed encapsulated flax oil with zein using sprayand freeze-drying. They observed that the amount of surface oil was low (less than 2\%) at a high zein/flax oil ratio. The content of surface oil in the powders was higher at low zein/ flax oil ratios and increased drastically with a decrease in the ratio to $10: 1$. These results demonstrate the importance of having sufficient quantities of the coating material to encapsulate the oil. The authors also observed the same dependency for the freeze-dried powder, where the surface oil content was reduced in the same proportion. In turn, Anwar and Kunz (2011) reported a high content of surface fish oil in freezedried powder $(11.83 \%)$ compared to oil powders obtained by spray-drying (2.63\%) and spray granulation (only $0.36 \%$ ).

Moisture content of the powders obtained with each production method or within the same spray-drying method was varied. The sample prepared by freeze-drying (EPO-4) had the lowest moisture content (2.4\%). Higher values (2.80 and $3.23 \%$ ) for freeze-dried oil were observed by Karaca et al. 
Table 2 Physicochemical characteristics of pumpkin seed oil powders

\begin{tabular}{|c|c|c|c|c|}
\hline \multirow[t]{2}{*}{ Parameter } & \multicolumn{4}{|l|}{ Powders } \\
\hline & EPO-1 & EPO-2 & EPO-3 & EPO-4 \\
\hline Surface oil ( $\%$ of powder) & $9.7 \pm 0.3 \mathrm{a}$ & $8.2 \pm 0.2 b$ & $9.6 \pm 0.3 \mathrm{a}$ & $9.2 \pm 0.8 \mathrm{a}$ \\
\hline Total oil (\% of powder) & $31.9 \pm 0.7 \mathrm{a}$ & $32.2 \pm 0.9 \mathrm{a}$ & $34.8 \pm 0.2 b$ & $31 \pm 1 \mathrm{a}$ \\
\hline Encapsulation efficiency (\%) & $69.4 \pm 0.3 \mathrm{a}$ & $74 \pm 1 \mathrm{c}$ & $72.4 \pm 0.8 b$ & $69 \pm 2 \mathrm{a}$ \\
\hline Moisture (\% of powder) & $4.14 \pm 0.05 \mathrm{a}$ & $3.66 \pm 0.02 b$ & $3.10 \pm 0.03 \mathrm{c}$ & $2.4 \pm 0.2 \mathrm{~d}$ \\
\hline Bulk density $\left(\mathrm{kg} / \mathrm{m}^{3}\right)$ & $314 \pm 8 c$ & $348 \pm 11 \mathrm{a}$ & $352 \pm 5 a$ & $158 \pm 1 b$ \\
\hline Wettability (s) & $>180 \pm 1 \mathrm{a}$ & $>180 \pm 1 \mathrm{a}$ & $>180 \pm 1 \mathrm{a}$ & $>180 \pm 1 \mathrm{a}$ \\
\hline Solubility index (cm) & $0.10 \pm 0.01 \mathrm{a}$ & $0.10 \pm 0.01 \mathrm{a}$ & $0.10 \pm 0.01 \mathrm{a}$ & $0.10 \pm 0.01 \mathrm{a}$ \\
\hline Mean diameter $\mathrm{D}(4,3)(\mu \mathrm{m})$ & $103 \pm 1 \mathrm{a}$ & $165 \pm 2 c$ & $136 \pm 2 b$ & n.d. \\
\hline Mean diameter $\mathrm{D}(3,2)(\mu \mathrm{m})$ & $58.6 \pm 0.5 \mathrm{a}$ & $86 \pm 1 \mathrm{c}$ & $74.0 \pm 0.5 b$ & n.d. \\
\hline \multicolumn{5}{|l|}{ Color components } \\
\hline $\mathrm{L}^{*}(\%)$ & $99.8 \pm 0.1 \mathrm{a}$ & $98.9 \pm 0.1 \mathrm{a}$ & $99.2 \pm 0.1 \mathrm{a}$ & $93.8 \pm 0.8 b$ \\
\hline $\mathrm{a}^{*}(-)$ & $-3.7 \pm 0.2 \mathrm{a}$ & $-4.1 \pm 0.2 \mathrm{a}$ & $-3.9 \pm 0.1 \mathrm{a}$ & $-7.1 \pm 0.6 b$ \\
\hline $\mathrm{b}^{*}(-)$ & $9.5 \pm 0.3 \mathrm{a}$ & $10.9 \pm 0.3 \mathrm{a}$ & $10.0 \pm 0.1 \mathrm{a}$ & $24 \pm 3 b$ \\
\hline
\end{tabular}

Mean values in lines denoted by the same letter do not differ statistically significantly at $\alpha<0.05$ (Duncan's test) n.d. not determined
(2013) who encapsulated flaxseed oil with employing chickpea and lentil protein isolates. In turn, in the study on spraydrying of acai, Tonon et al. (2008) reported moisture content to vary from 0.64 to $2.89 \%$. It is well known that the moisture content of powders has a significant effect on storage stability.

Powders are frequently used for convenience in applications for transportation, handling, processing, and product formulation. Powders possess physical and functional properties which are significant in terms of their applicability, including powder structure, particle size distribution, powder density, bulk density, particle density, and rehydratation (Sharma et al. 2012). Bulk density, also known as apparent or packing density, is a measure of the mass of powder which occupies a fixed volume. In this study, the lowest bulk density was obtained in the samples prepared by FD $\left(158.20 \mathrm{~kg} \mathrm{~m}^{-3}\right)$, while in the samples obtained by SD, all values were above $300 \mathrm{~kg} \mathrm{~m}^{-3}$. The bulk densities of freeze-dried samples are comparable to data reported by Quispe-Condori et al. (2011). These authors observed also that the spray-dried powder produced at a low zein/flax oil ratio was denser than the powder produced at a high zein/flax oil ratio.

If a mixture of powders is used for the preparation of reconstituted drinks, some characteristics should be considered, namely, wettability, dispersibility, and solubility (Celli et al. 2015). In our study, values of rehydration parameters were the same for all samples: wettability was above $180 \mathrm{~s}$, while solubility index was $0.1 \mathrm{~cm}$. Wettability is related to the capacity of the powder to absorb water on the surface, and it is the initial stage of the reconstitution process. It is probably affected by particle size and the presence of lipids on the surface (Celli et al. 2015).

\section{Impact of Emulsion Treatment Before Drying}

In our study, two-step homogenization (first step - 240 bar, second step -40 bar) was applied to prepare the encapsulated oil. Only one spray-dried emulsion was homogenized before drying (EPO-3), and it had the highest content of total oil $(34.8 \%)$ and the lowest moisture content (3.10\%). Sample EPO-4 was also homogenized before freeze-drying, but in this case, the difference in data between the samples results rather from process parameters of drying. Hogan et al. (2001) found that moisture contents of spray-dried soya oil emulsions encapsulated with whey protein concentrate (WPC) were not affected by homogenization pressure or oil/protein ratio. These authors reported also that homogenization pressure higher than 100 bar had no effect on encapsulation efficiency of soybean oil with sodium caseinate. Ixtaina et al. (2015) reported that the homogenization pressure applied during emulsification had a greater influence on the physicochemical properties of the powder and the reconstituted emulsion than the inlet/outlet temperatures applied during spray-drying. In their study, when pressure of 600 bar was used for the emulsification prior to the drying process, the moisture content and water activity of the powder were lower than in the case of the 400-bar treatment. Also, the physical stability of the reconstituted emulsions was higher at 600 bar.

\section{Impact of Spray-Drying Inlet Temperature}

Several studies reported that at higher inlet air temperatures, there is a greater temperature gradient between the atomized feed and the drying air, which results in a greater driving force 
for water evaporation and thus in the production of powders with a lower moisture content. In an experiment carried by Tonon et al. (2008), temperature was the variable that had the greatest influence on powder moisture content. Aghbashlo et al. (2013) observed that increasing the inlet temperature of drying air accelerated the moisture evaporation rate, which resulted in a lower moisture content of the finished product. This conclusion does not correspond with results of our study, where the highest moisture content $(4.14 \%)$ was obtained by SD with the highest inlet temperature $\left(180^{\circ} \mathrm{C}\right)$, followed by EPO-2 (3.66\%) and EPO-3 (3.10\%).

Our study showed that as the inlet drying air temperature increased, the bulk density of encapsulated oil decreased. The lowest value $\left(314 \mathrm{~kg} \mathrm{~m}^{-3}\right)$ was obtained in the sample prepared by spray-drying at $180{ }^{\circ} \mathrm{C}$ (EPO-1), the highest one $\left(352 \mathrm{~kg} \mathrm{~m}^{-3}\right.$ ) in the sample obtained by spray-drying at $130{ }^{\circ} \mathrm{C}$ with emulsion homogenization before drying (EPO3). According to Tonon et al. (2011), the higher drying air temperatures are associated with lower bulk density. In their study, milk-originated wall materials were used to encapsulation of fish oil by spray-drying at various inlet drying air temperatures. Bulk density was the lowest in all variants obtained at a temperature of $180{ }^{\circ} \mathrm{C}$, and the results differed significantly $(p<0.05)$ from those of the samples obtained at 140 and $160{ }^{\circ} \mathrm{C}$. Higher drying air temperature increases the drying rate and, therefore, accelerates the migration of crustforming soluble materials to the surface of atomizer droplets. The rapid formation of a dried crust layer on the surface of the droplets hinders the shrinkage of particles, and larger capsules are obtained (Chegini and Ghobadian 2005), resulting in a lower bulk density (Aghbashlo et al. 2013).

Our study demonstrated also that the higher inlet drying temperature generated more free oil. In the case of spraydrying at $180{ }^{\circ} \mathrm{C}$ (EPO-1), 31\% of total encapsulated oil was in the form of free fat, whereas upon the use of the lower temperature this value was reduced to $25 \%$ (EPO-2). Our results correspond to those obtained by Drusch and Berg (2008) who investigated properties of encapsulated fish oil prepared under different inlet and outlet spray-drying temperatures (at $160 / 60{ }^{\circ} \mathrm{C}$ and $210 / 90{ }^{\circ} \mathrm{C}$ ). They showed that at the higher inlet/outlet temperature, the amount of non-encapsulated oil was twofold higher than at the lower temperature, irrespectively of oil load. Moreover, Kelly et al. (2014) obtained powders from vegetable oils with a higher free fat level when a higher outlet temperature had been used.

\section{Color, Size, and Morphology of Pumpkin Seed Oil Powders}

Results of color measurements of powders expressed by $\mathrm{L}^{*}$, $\mathrm{a}^{*}$, and $\mathrm{b}^{*}$ components are shown in Table 2. All powders were very light ( $\mathrm{L}^{*}$ close to $100 \%$ ) and had a green-yellow color (negative $a^{*}$ and positive $b^{*}$ ). Significant differences were found for powder obtained by freeze-drying. They were characterized by the lowest $\mathrm{L}^{*}$ and $\mathrm{a} *$ values $(93.8 \%$ and -7.1 , respectively) and the highest $\mathrm{a}^{*}$ value $(24)$. The statistically significant differences in the color of the powders obtained by spray- and freeze-drying may be explained by differences in the size and shape of particles. As can be seen, a decrease in particle size caused an increase in lightness and a decrease in the greenness and yellowness (Table 2). The significant effect of particle size on the $\mathrm{L}^{*}$ component was also confirmed by other researches, e.g., Sharma et al. (2013) who studied properties of mango pulp powders.

Furthermore, it was noted that the higher temperature of spray-drying leads to lightening. This phenomenon may be explained by a shorter time of drying in the case of EPO-1, which reduced color degradation. The same relationship was reported by Caparino et al. (2012) who investigated the influence of different drying methods on the physical properties of mango powder. The color of pumpkin seed oil powders is distinctly different from typical pumpkin seed oil. In our earlier study, we found that laboratory cold-pressed pumpkin seed oil was characterized by $\mathrm{L}^{*}=82.9 \%$, $\mathrm{a}^{*}=-12.9$, and $b^{*}=37.1$ (data not shown).

Based on the measurements of surface and volume diameters $(\mathrm{D}(4,3)$ and $\mathrm{D}(3,2)$, respectively), it was shown that conditions of the spray-drying experiment had a statistically significant effect $(p \leq 0.05)$ on powder particle size. The smallest particles with $\mathrm{D}(4,3)$ at $103 \mu \mathrm{m}$ and $\mathrm{D}(3,2)$ at $58.6 \mu \mathrm{m}$ were typical of EPO-1, whereas the particles obtained by EPO-2 were characterized by $\mathrm{D}(4,3)$ at $165 \mu \mathrm{m}$ and $\mathrm{D}(3,2)$ at $86 \mu \mathrm{m}$ (Table 2). Kelly et al. (2014), who produced spraydried powders from sunflower and palm oils using similar inlet/outlet temperatures $\left(185 / 90{ }^{\circ} \mathrm{C}\right)$ to those used in our experiment (EPO-1), obtained smaller particles with an average size expressed as $\mathrm{D}(4,3)$ of approx. $80 \mu \mathrm{m}$.

Generally, capsules obtained at the lower inlet temperature were greater in size, but homogenization of the emulsion that had been applied before drying reduced the size of particles. According to Ixtaina et al. (2015), homogenization pressure used for emulsifying has a greater influence on capsule size than spray-drying inlet/outlet temperatures. In turn, the particle size of spray-dried powder is also dependent on the type and concentration of the wall material. Najafi et al. (2011) showed that modified starch (Hi-Cap 100) resulted in larger particles compared to skim milk powder. Additionally, when they changed the wall material concentration from 10 to $30 \%$, the value of $\mathrm{D}(3,2)$ increased by approx. $42 \%$.

Ixtaina et al. (2015), who studied properties of chia oil encapsulated by spray-drying, obtained smaller (3-12 $\mu \mathrm{m})$, unified, and more spherical particles by using higher pressure (400 bar) for homogenization of emulsion than in our study. Moreover, these authors demonstrated that when homogenization pressure increased to 600 bar, values of the volumetric and surface diameters decreased significantly. 
In our study, the smaller particle size of the spray-dried powder corresponded with a higher content of surface oil. It is in accordance with findings reported by Anwar and Kunz (2011) who studied powders prepared from fish oil.

Figure 1 shows the particle size distribution curves only for spray-dried samples. The EPO-4 sample particle size was not presented due to their different structure and great diversity in size of particles. The curves plotted for the powders obtained from non-homogenized emulsions (EPO-1 and EPO-2) were unimodal and showed a normal shape. In turn, the powder obtained from homogenized emulsion (EPO-3) exhibited a similar size range but greater variability.

The morphology of capsules was observed by SEM (Fig. 2). The SEM images of spray-dried powders show separated capsules with cracks and pores. The capsules obtained at the higher inlet temperature (EPO-1) were approximately spherical in shape with some wrinkles or scars on the surface, while other capsules obtained with the same technique (EPO2 and EPO-3) were more deformed. Figure $2 d$ is a typical image of emulsion encapsulated by freeze-drying. The freeze-dried material showed a completely different morphology of particles, typical of flakes. It consisted mostly of particles larger than $300 \mu \mathrm{m}$ in diameter with pores and wrinkles visible on the surface. Najafi et al. (2011) also confirmed that, unlike freeze-drying, the spray-drying technique allows obtaining a spherical shape of oil capsules.

The heat used in spray-drying can cause microcracks on the surface of the particles that can negatively affect the stability of the encapsulated bioactive compounds (Jones et al. 2013). While during freeze-drying processing, a barrier with an open porous structure is formed between the active agent and its surroundings, and this highly porous wall ensures poor protection when prolonged release of an active compound is required (Nedovic et al. 2011).
Figure 3 depicts the effect of drying conditions on capsule formation. The samples were characterized by capsules with both large and small oil droplets, and free oil was also prevalent. When homogenization was applied, multiple smaller oil droplets became entrapped within the capsules. Multinuclear capsules are generally considered as having better controlled release properties than mononuclear ones. The first type of capsules are capable of releasing their contents slowly over time upon complete or partial degradation of the matrix, whereas the second type release their contests instantly (Liu et al. 2010).

\section{Fatty Acid Composition of Encapsulated Pumpkin Seed Oil}

Table 3 presents results of fatty acid composition determination. Linoleic acid was found to predominate in the pumpkin seed oil, with the content accounting for $64.3 \%$. Contents of other fatty acids, i.e., oleic, palmitic, and stearic fatty acids, were at $19.2,11.1$, and $5.4 \%$, respectively. These results correspond with findings reported by other authors. For instance, Neđeral et al. (2014) showed linoleic acid to be the predominating fatty acid in all analyzed samples of oil pressed from seeds of pumpkin grown in different years in Croatia. Its content ranged from 44.45 to $47.49 \%$ in oils pressed from the seeds from the 2010/2011 season and from 44.04 to $45.79 \%$ in those from the 2011/2012 season. Linoleic acid was also a predominating fatty acid in a study conducted by Procida et al. (2013), who analyzed oil produced from seeds of pumpkin grown in Italy $(44.30-51.58 \%)$ and Slovenia (44.69$51.28 \%)$.

The encapsulation generally helped preserve unsaturated fatty acids such as C18:1 (omega-9 FA), C18:2 (omega-6 FA), and C18:3 (omega-3 FA) (Ruiz et al. 2015). The
Fig. 1 The particle size distribution of spray-dried powders

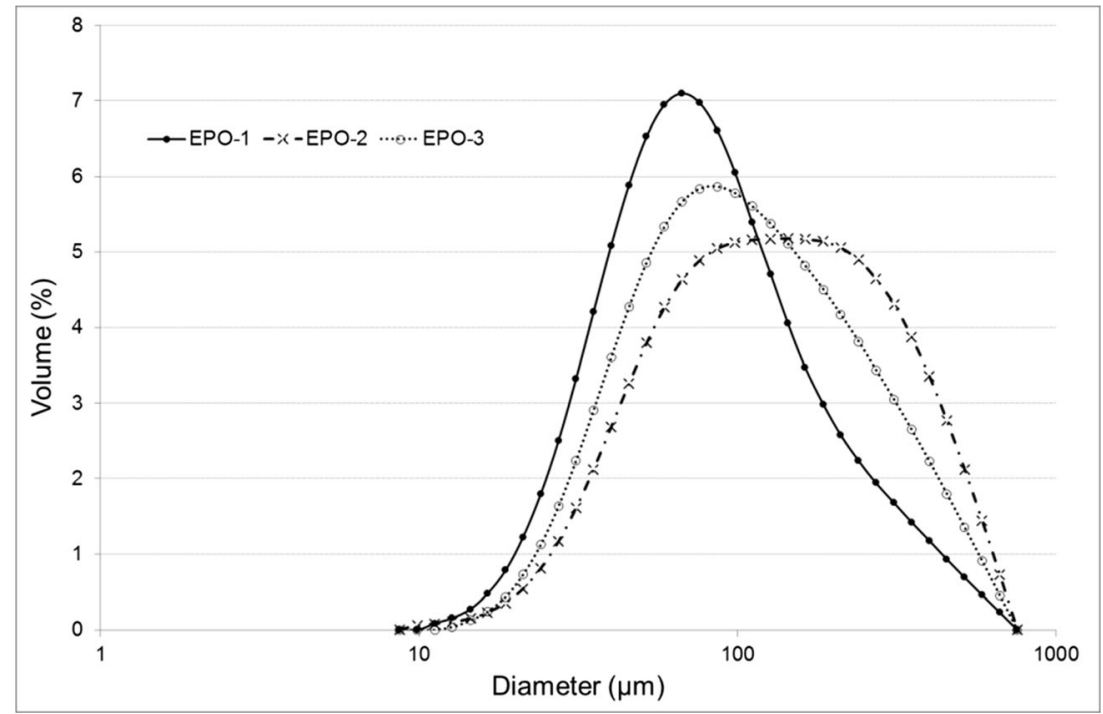


analyzed samples of encapsulated pumpkin seed oil were characterized by $6-7 \%$ lower proportion of polyunsaturated fatty acids (PUFA), by 9-11\% higher proportion of monounsaturated fatty acids (MUFA), and by $10-14 \%$ higher saturated fatty acids (SFA) (Table 3). The observed changes in fatty acids generally agreed with previous findings reported in literature, e.g., the loss of unsaturated fatty acids normally increased with heating time and temperature (Choe and Min 2007), and unsaturated fatty acids are more susceptible to oxidation than the saturated fatty acids (Roszkowska et al. 2015). Also, Calvo et al. (2011) observed a similar dependency when analyzing encapsulated walnut oil, in which the content of linoleic acid was lower by $0.5-3.5 \%$ compared to the control sample. Results of our study also demonstrated that homogenization of the emulsion before spray-drying had no significant influence $(p<0.05)$ on PUFA losses.

\section{Bioactive Compound Content in Encapsulated Pumpkin Seed Oil}

Many functional lipids including polyunsaturated lipids such as omega- 3 fatty acids and conjugated linoleic acids and lipidsoluble bioactives such as carotenoids, coenzyme Q10, tocopherols, and some vitamins are sensitive to oxidation. If not adequately protected from the environment, they can degrade very rapidly. It results in the development of off-flavors and reduced bioactivity (Augustin and Sanguansri 2008).

Table 4 summarizes results of bioactive compound characteristics of the control oil and encapsulated oils used in this study. The oils were characterized by typical contents of tocopherols, squalene, and sterols for the cold-pressed pumpkin seed oil.

The content of tocopherols in the control pumpkin seed oil reached $53 \mathrm{mg} / 100 \mathrm{~g}$ of oil. The predominating isomers were $\gamma$-and $\delta$-tocopherols, the total content of which was at $45 \mathrm{mg} /$ $100 \mathrm{~g}$ of oil (Table 4). In addition, $\alpha$-tocopherol was identified in the oil with the content at $7.98 \mathrm{mg} / 100 \mathrm{~g}$ of oil. The above results are consistent with findings reported by NawirskaOlszańska et al. (2013), who determined a low content or no $\beta$-tocopherol in six cultivars of Cucurbita maxima and Cucurbita pepo seeds. A similar tocopherol content, ranging from 44.5 to $64.1 \mathrm{mg} / 100 \mathrm{~g}$ of oil, was determined by Rabrenović et al. (2014). In their experiment, $\beta$ - and $\gamma$ tocopherols were predominating compounds with a total content ranging from 32.36 to $53.60 \mathrm{mg} / 100 \mathrm{~g}$ of oil. In turn, Górnaś et al. (2014) reported $\gamma$-tocopherol to be the
Fig. 2 SEM images of spraydried and freeze-dried powders: EPO-1 (a), EPO-2 (b), EPO-3 (c), and EPO-4 (d)
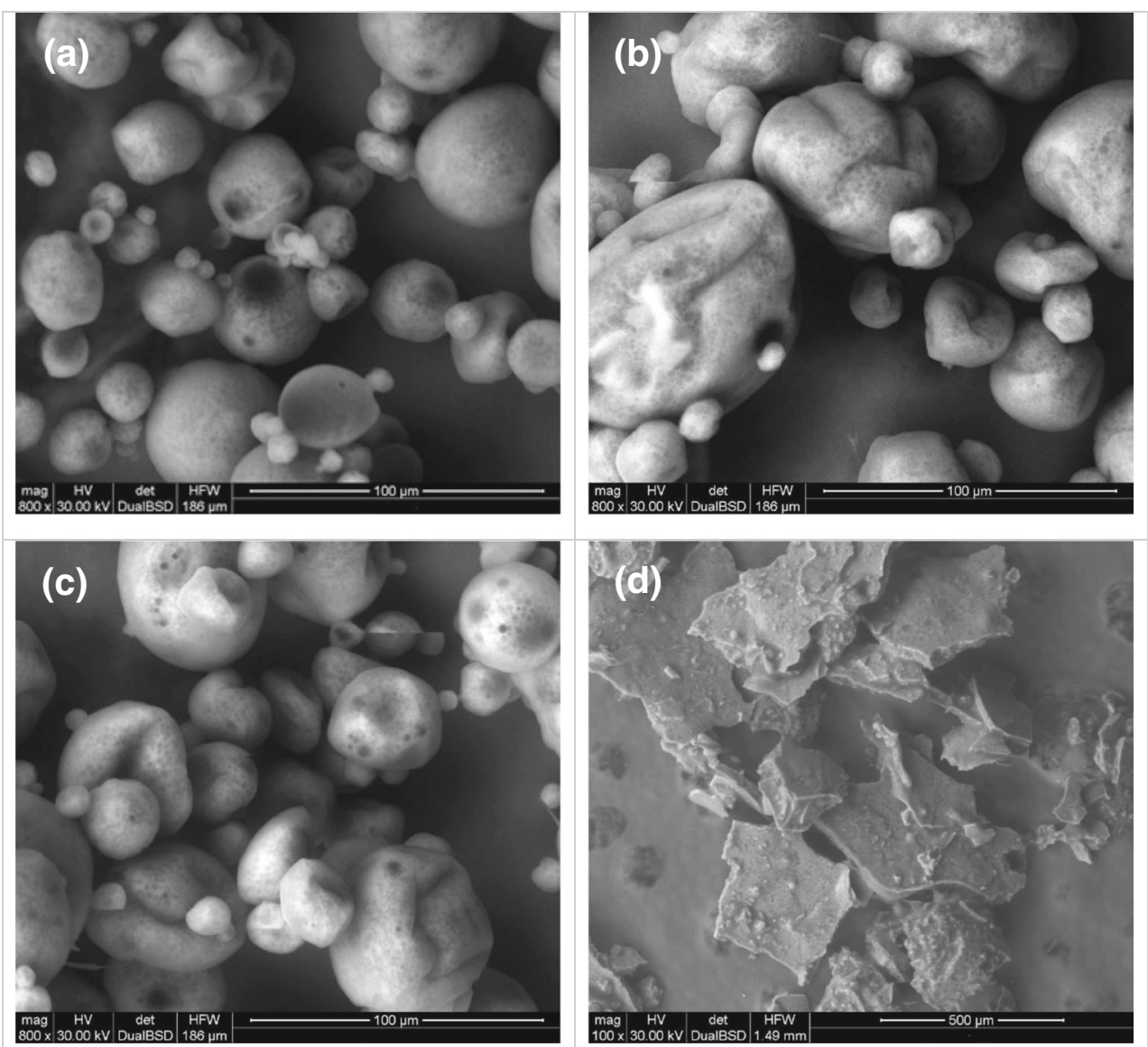
Fig. 3 Confocal microscope images of spray-dried and freezedried powders dissolved in 50\% glycerol $(v / v)$ containing Sudan solution ( $2 \%$ in ethanol, $w / v)$ : EPO 1 (a), EPO-2 (b), EPO-3 (c), and EPO-4 (d). Solid arrow represents capsule, dotted arrow represents shell, and dashed arrow represents free fat
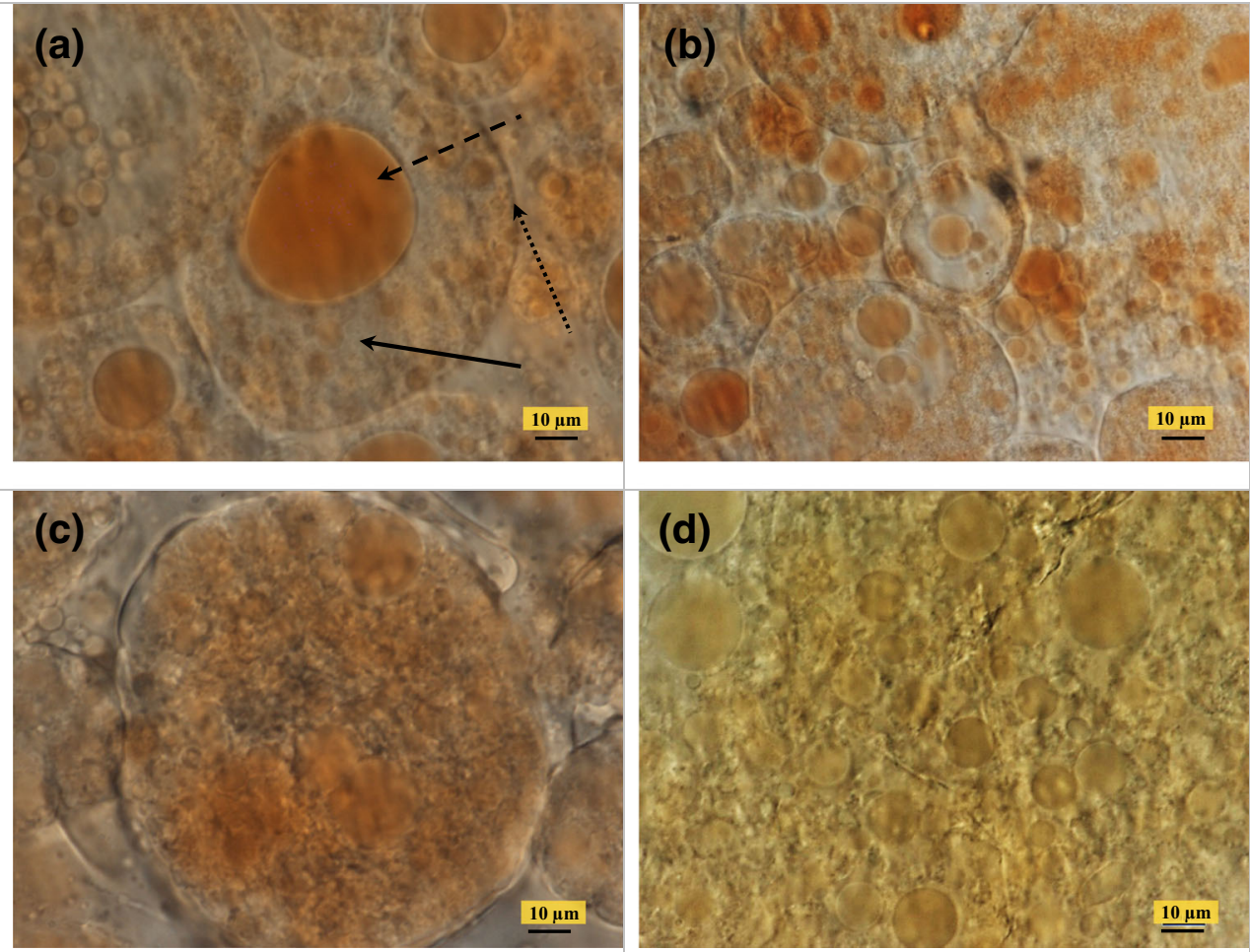

predominating isomer of pumpkin seed oil with the content reaching $44.24 \mathrm{mg} / 100 \mathrm{~g}$ of oil.

Analogously to the control sample, the sum of $\gamma$ - and $\delta$ tocopherols was the predominating form of isomers in encapsulated pumpkin seed oil. The greatest degradation of tocopherols was observed in the samples obtained by freeze-drying (EPO-4) when the content of $\alpha$-tocopherol decreased by $71.2 \%$, the content of $\gamma$-Tc $+\delta$-Tc by $69.8 \%$. The least losses of $\alpha$-Tc isomers were found in the EPO-2 sample (56.3\%), the least losses of the sum $\gamma$-Tc $+\delta$-Tc in the EPO- 1 sample $(55.3 \%)$. Generally, our study indicates that long-term aeration of the sample $(72 \mathrm{~h})$ during freeze-drying caused greater degradation of this group of compounds compared to shortterm high-temperature treatment. Opposite results were achieved by Calvo et al. (2011, 2012), who encapsulated walnut and olive oils with the method of freeze-drying and found
Table 3 Fatty acid compositions (\%) of control and encapsulated pumpkin seed oils

\begin{tabular}{llllll}
\hline Fatty acids & Control oil & \multicolumn{2}{l}{ Powders } & & \\
\cline { 3 - 6 } & & EPO-1 & EPO-2 & EPO-3 & EPO-4 \\
\hline Palmitic $(\mathrm{C} 16: 0)$ & $11.1 \pm 0.1 \mathrm{~b}$ & $12.2 \pm 0.6 \mathrm{a}$ & $12.6 \pm 0.1 \mathrm{a}$ & $12.6 \pm 0.4 \mathrm{a}$ & $12.7 \pm 0.2 \mathrm{a}$ \\
Stearic $(\mathrm{C} 18: 0)$ & $5.4 \pm 0.1 \mathrm{c}$ & $6.0 \pm 0.1 \mathrm{a}$ & $6.2 \pm 0.1 \mathrm{~b}$ & $6.3 \pm 0.2 \mathrm{~b}$ & $5.9 \pm 0.1 \mathrm{a}$ \\
Oleic $(\mathrm{C} 18: 1)$ & $19.2 \pm 0.5 \mathrm{~b}$ & $21.1 \pm 0.1 \mathrm{a}$ & $20.9 \pm 0.7 \mathrm{a}$ & $21.4 \pm 0.1 \mathrm{a}$ & $20.9 \pm 0.5 \mathrm{a}$ \\
Linoleic $(\mathrm{C} 18: 2)$ & $64.3 \pm 0.7 \mathrm{c}$ & $60.7 \pm 0.6 \mathrm{~b}$ & $60.2 \pm 0.7 \mathrm{ab}$ & $59.7 \pm 0.5 \mathrm{a}$ & $60.4 \pm 0.3 \mathrm{ab}$ \\
Linolenic $(\mathrm{C} 18: 3 \alpha)$ & Trace & Trace & Trace & Trace & Trace \\
SFA & $16.5 \pm 0.2 \mathrm{c}$ & $18.2 \pm 0.7 \mathrm{~b}$ & $18.8 \pm 0.1 \mathrm{a}$ & $18.9 \pm 0.6 \mathrm{a}$ & $18.6 \pm 0.2 \mathrm{ab}$ \\
Increase of SFA $(\%)^{\mathrm{a}}$ & - & 10.3 & 13.9 & 14.5 & 12.7 \\
MUFA & $19.2 \pm 0.5 \mathrm{~b}$ & $21.1 \pm 0.1 \mathrm{a}$ & $20.9 \pm 0.7 \mathrm{a}$ & $21.4 \pm 0.1 \mathrm{a}$ & $20.9 \pm 0.5 \mathrm{a}$ \\
Increase of MUFA $(\%)^{\mathrm{a}}$ & - & 9.9 & 8.8 & 11.5 & 8.8 \\
PUFA & $64.3 \pm 0.7 \mathrm{c}$ & $60.7 \pm 0.6 \mathrm{~b}$ & $60.2 \pm 0.7 \mathrm{ab}$ & $59.7 \pm 0.5 \mathrm{a}$ & $60.4 \pm 0.3 \mathrm{ab}$ \\
Decrease of PUFA $(\%)^{\mathrm{a}}$ & - & 5.7 & 6.3 & 7.1 & 6.0 \\
\hline
\end{tabular}

Mean values in lines denoted by the same letter do not differ statistically significantly at $\alpha<0.05$ (Duncan's test) SFA saturated fatty acids, MUFA monounsaturated fatty acids, PUFA polyunsaturated fatty acids

${ }^{a}$ Increase/decrease compared to the control sample 
Table 4 Bioactive compounds of control and encapsulated pumpkin seed oils

\begin{tabular}{|c|c|c|c|c|c|}
\hline \multirow[t]{2}{*}{ Parameter } & \multirow[t]{2}{*}{ Control oil } & \multicolumn{4}{|l|}{ Powders } \\
\hline & & EPO-1 & EPO-2 & EPO-3 & EPO-4 \\
\hline \multicolumn{6}{|l|}{ Tocopherols (mg/100 g of oil) } \\
\hline$\alpha-\mathrm{Tc}$ & $7.98 \pm 0.02 \mathrm{a}$ & $3.67 \pm 0.01 \mathrm{~b}$ & $3.5 \pm 0.1 \mathrm{c}$ & $3.2 \pm 0.1 \mathrm{~d}$ & $2.30 \pm 0.01 \mathrm{e}$ \\
\hline Decrease $^{\mathrm{a}}(\%)$ & - & 59.2 & 56.3 & 59.6 & 71.2 \\
\hline$\gamma-\mathrm{Tc}+\delta-\mathrm{Tc}$ & $45 \pm 1 d$ & $20.24 \pm 0.04 \mathrm{c}$ & $14 \pm 1 \mathrm{ab}$ & $16 \pm 2 b$ & $13.7 \pm 0.4 \mathrm{a}$ \\
\hline Decrease $^{\mathrm{a}}(\%)$ & - & 55.3 & 68.7 & 65.0 & 69.8 \\
\hline Total & $53 \pm 1 d$ & $23.01 \pm 0.04 \mathrm{c}$ & $17.6 \pm 0.9 \mathrm{ab}$ & $19 \pm 3 b$ & $16.0 \pm 0.5$ \\
\hline Decrease $^{\mathrm{a}}(\%)$ & - & 55.1 & 66.9 & 64.2 & 70.0 \\
\hline \multicolumn{6}{|l|}{ Squalene (mg/100 g of oil) } \\
\hline Squalene & $1192 \pm 58 \mathrm{~d}$ & $906 \pm 45 a$ & $997 \pm 41 \mathrm{c}$ & $675 \pm 3 b$ & $851 \pm 51 \mathrm{a}$ \\
\hline Decrease $^{\mathrm{a}}(\%)$ & - & 24.0 & 16.4 & 43.4 & 28.6 \\
\hline \multicolumn{6}{|l|}{ Sterols (mg/100 g of oil) } \\
\hline Cholesterol & - & $143 \pm 21 \mathrm{a}$ & $217 \pm 13 b$ & $153 \pm 7 \mathrm{a}$ & $274 \pm 5 c$ \\
\hline Spinasterol $+\beta$-sitosterol & $601 \pm 48 c$ & $423 \pm 21 \mathrm{a}$ & $537 \pm 71 b$ & $423 \pm 20 \mathrm{a}$ & $575 \pm 13 b c$ \\
\hline Decrease $^{\mathrm{a}}(\%)$ & - & 29.5 & 10.7 & 29.7 & 4.3 \\
\hline$\Delta 7,22,25$-stigmastatrienol & $257 \pm 15 \mathrm{~d}$ & $171 \pm 10 \mathrm{a}$ & $220 \pm 18 b$ & $168 \pm 7 \mathrm{a}$ & $240 \pm 2 c$ \\
\hline Decrease $^{\mathrm{a}}(\%)$ & - & 33.2 & 14.1 & 34.5 & 6.2 \\
\hline$\Delta 7$-stigmasterol & $46 \pm 4 a$ & $29 \pm 7 b$ & $41 \pm 4 \mathrm{a}$ & $31.3 \pm 0.3 b$ & $46 \pm 4 \mathrm{a}$ \\
\hline Decrease $^{\mathrm{a}}(\%)$ & - & 38.0 & 12.1 & 32.2 & 0.30 \\
\hline$\Delta 7,25$-stigmastadienol & $282 \pm 29 c$ & $185 \pm 14 \mathrm{a}$ & $237 \pm 15 b$ & $172 \pm 9 a$ & $263 \pm 5 c$ \\
\hline Decrease $^{\mathrm{a}}(\%)$ & - & 34.3 & 15.9 & 38.9 & 6.7 \\
\hline Total & $1186 \pm 96 b$ & $952 \pm 30 \mathrm{a}$ & $1252 \pm 20 \mathrm{~b}$ & $947 \pm 44 \mathrm{a}$ & $1399 \pm 7 \mathrm{c}$ \\
\hline Decrease $^{\mathrm{a}}(\%)$ & - & 19.8 & - & 20.1 & - \\
\hline
\end{tabular}

Mean values in lines denoted by the same letter do not differ statistically significantly at $\alpha<0.05$ (Duncan's test)

${ }^{\text {a }}$ Decrease compared to the control sample

that the content of tocopherols in the encapsulated samples differed insignificantly from that assayed in the samples of control oils. In general, high degradation of tocopherols in all analyzed powders could be explained by the presence of light and oxygen during the drying process (Anwar and Kunz 2011) since these compounds are not resistant to high temperatures (Bruscatto et al. 2009). Furthermore, the homogenization process might decrease tocopherols too. However, Serfert et al. (2009) reported no increase of lipid oxidation products in oil samples indicating chemical stabilization during the homogenization experiments.

Squalene $\left(\mathrm{C}_{30} \mathrm{H}_{50}\right)$ is a colorless isoprenoid unsaturated hydrocarbon that possesses six double trans bonds. This compound plays a key role in extinguishing free radicals, which prevents negative effects of lipid peroxidation, and, together with phenolic compounds contained in, e.g., olive oil, protects against atherosclerosis (Reddy and Couvreur 2009). In the presented experiment, the content of squalene in the control sample reached $1192 \mathrm{mg} / 100 \mathrm{~g}$ of oil, which is a high value compared to literature data. According to Gorjanović et al. (2011), squalene content in oils produced from seeds of C. pepo hulless pumpkin ranged from $549 \mathrm{mg} / 100 \mathrm{~g}$ of oil (cultivar "SB"-Serbia) to $788 \mathrm{mg} / 100 \mathrm{~g}$ of oil (cultivar "Gleisdorfer Diamant"-Austria). The analysis of results obtained in our study enables concluding that squalene is a compound characterized by high lability. Its degradation was the lowest in the EPO-2 sample (16.4\%) and the highest in the EPO-3 sample (43.4\%). Both these samples were prepared by spray-drying at $130{ }^{\circ} \mathrm{C}$, but the EPO-3 sample was additionally homogenized before drying. In turn, freeze-drying of pumpkin oil had less unfavorable impact on squalene content in comparison to spray-drying. Dos Santos et al. (2014) investigated the influence of different procedures of pulp drying before oil extraction on the concentrations of bioactive compounds. They showed that hot air drying at $70{ }^{\circ} \mathrm{C}$ resulted in smaller concentrations of squalene in oil. Ogrodowska et al. (2014) analyzed the effect of puffing and flaking amaranth seeds on contents of biologically active compounds. They found that the high-temperature and high-pressure treatments contributed to squalene losses. The content of squalene in seeds reached $469.96 \mathrm{mg} / 100 \mathrm{~g}$ of seeds, whereas in products made of them it accounted for $428.64 \mathrm{mg} / 100 \mathrm{~g}$ of product (popping) and $358.90 \mathrm{mg} / 100 \mathrm{~g}$ of product (flakes). Worthy of notice is also that popping was characterized by a porous 
structure, flakes by a large specific surface, which could also affect squalene degradation.

Owing to a high content and appropriate composition of sterols, the pumpkin seed oil is characterized by healthpromoting properties that are exploited by pharmacists. These compounds may prevent cancers, atherosclerosis, and inflammatory conditions (Ryan et al. 2005). The sum of sterols in the oil intented for encapsulation reached $1186 \mathrm{mg} /$ $100 \mathrm{~g}$ of oil. It included the following sterols: spinasterol + $\beta$-sitosterol ( $601 \mathrm{mg} / 100 \mathrm{~g}$ of oil), $\Delta 7,22,25$-stigmastatrienol (257 mg/100 g of oil), $\Delta 7$-stigmasterol (46 mg/100 g of oil), and stigmastadienol ( $282 \mathrm{mg} / 100 \mathrm{~g}$ of oil). Rabrenović et al. (2014) presented a similar composition of sterols; however, they additionally identified $\Delta 7$-avenasterol, and the total sterol content determined in their study ranged from 718.1 to $897.8 \mathrm{mg} / 100 \mathrm{~g}$ of oil. In all analyzed samples of encapsulated pumpkin seed oil, analyses revealed the presence of cholester$\mathrm{ol}$, with the content ranging from $143 \mathrm{mg} / 100 \mathrm{~g}$ of oil (EPO-1) to $274 \mathrm{mg} / 100 \mathrm{~g}$ of oil (EPO-4). It is not classified as a phytosterol, but it was a component of capsule coat - in this case, of milk protein concentrate. The total sterol contents differed statistically significantly among the individual samples and ranged from $947 \mathrm{mg} / 100 \mathrm{~g}$ of oil (EPO-3) to $1399 \mathrm{mg} / 100 \mathrm{~g}$ of oil (EPO-4). The oil encapsulated by freeze-drying was characterized by the lowest decrease of total sterols. In this case, the sum of spinasterol and $\beta$-sitosterolu decreased by only $4.3 \%$ compared to the control sample. A small decrease in sterol content was also noted in the EPO-2 sample, i.e., $13 \%$ on average for individual sterols. In the remaining analyzed samples, degradation of sterols was significantly greater. The least stable sterol in the EPO-1 sample turned out to be $\Delta 7$ stigmasterol (decrease by $38.0 \%$ ), in the EPO-3 sample, $\Delta 7,25$-stigmastadienol (decrease by $38.9 \%$ ). In both samples, the most stable compounds appeared to be spinasterol $+\beta$ sitosterol whose losses accounted for 29.5\% (EPO-1) and $29.7 \%$ (EPO-3). The samples characterized by the greatest decrease of sterols were the most exposed to the effects of factors unfavorable to thermolabile substances. In the case of the EPO-1 sample, this was a high temperature of drying $\left(180^{\circ} \mathrm{C}\right)$, and in the case of the EPO-3 sample, it was additionally homogenization of the emulsion before drying.

Chen et al. (2013) analyzed stability of powders constituted by fish oil, phytosterols, limonene, and milk proteins, produced upon spray-drying. After 7 days of storage, the content of limonene decreased singificantly, whereas the content of phytosterols remained unchanged. It is due to the fact that although the applied process parameters caused the greatest losses of sterols, the appropriate conditions of storage inhibited further degradation of these compounds. Soupas et al. (2006) studied changes occuring in phytosterol in phytosterol-enriched foods during processing (spray-drying at $165-192{ }^{\circ} \mathrm{C}$ ) and storage by analyzing the formation of major secondary oxidation products and contents of unoxidized phytosterols. In their experiment, phytosterols in microcrystalline suspensions in different fats/oils were stable at $4{ }^{\circ} \mathrm{C}$ over a 12 -month storage period. Total contents of sitosterol oxides were virtually the same as in the control sample. The determined contents of oxides ranged from "not detected" to $54.2 \mu \mathrm{g} / \mathrm{g}$ of products in suspensions containing $18 \%$ phytosterols and from 26.7 to $109 \mu \mathrm{g} / \mathrm{g}$ of products in suspensions containing $30 \%$ phytosterols. In addition, the main sitosterol oxides in all suspensions studied were $7 \beta$ hydroxysitosterol and $5 \alpha, 6 \alpha$ - or $5 \beta, 6 \beta$-epoxysitosterols.

The unbeneficial effects of high-temperature treatments were also confirmed by Barriuso et al. (2012), who demonstrated that even a 5 -min heating of the sample at $180{ }^{\circ} \mathrm{C}$ caused a $41.80 \%$ loss of cholesterol, a $58.06 \%$ loss of campesterol, a $56.12 \%$ loss of sigmasterol, and a $61.45 \%$ loss of sitosterol. The same process conditions resulted in the formation of toxic sterol oxidation derivatives, including mainly 5,6 - $\beta$-epoxycampesterol $(0.38 \mu \mathrm{g} / \mathrm{mg}$ campesterol $)$ and $5,6-\alpha$-epoxycholesterol $(0.25 \mu \mathrm{g} / \mathrm{mg}$ cholesterol $)$. In turn, Obara et al. (2006) investigated the influence of water content on the accumulation of oxysterols in spray-dried and freezedried whole egg and egg yolk powder during 3 months of storage at room temperature. In their study, considering the effect of the drying method of powders, no significant changes were observed in the level of the following oxysterols: $7 \alpha$ hydroxycholesterol, $5 \beta, 6 \beta$-epoxycholesterol, $7 \beta$ hydroxycholesterol, and 7-ketocholesterol. Spray-dried egg powders contained significantly more $5 \alpha, 6 \alpha$ epoxycholesterol than the freeze-dried egg powders.

\section{Pigment Composition in Encapsulated Pumpkin Seed Oil}

Table 5 lists results of spectrophotometric analysis of pigments in pumpkin seed oils. Control oil was characterized by an intensive red-green color, and it was confirmed by high absorption values. The total color value for native oil was 1428 , while for encapsulated oils it was in the range 11371192 .

Chlorophyll is known as a photosensitizing molecule of a singlet oxygen under light and as a very important factor that affects oxidative stability of oils, especially those exposed to light radiation (Lee et al. 1997). Pumpkin seed oil is characterized by a significantly higher content of chlorophylls, up to $6 \mathrm{mg} / \mathrm{kg}$, whereas in most edible oils the level of these pigments is below $1 \mathrm{mg} / \mathrm{kg}$ (Górnaś et al. 2014). In contrast to chlorophylls, carotenoids act as antioxidants in stored oils. They are considered the most effective compounds in inhibiting photosensibilized oxidation (Beutner et al. 2001). The content of carotenoids in pumpkin seed oils reaches 19$23 \mathrm{mg} / \mathrm{kg}$ (Procida et al. 2013).

Encapsulation of oil, regardless of the method applied, decreased the content of pigments. The values of absorption measured for chlorophylls and carotenoids decreased by 13- 
Table 5 Oxidative stability, pigment characteristics, and total color of control and encapsulated pumpkin seed oils

\begin{tabular}{|c|c|c|c|c|c|}
\hline \multirow[t]{2}{*}{ Parameter } & \multirow[t]{2}{*}{ Control oil } & \multicolumn{4}{|l|}{ Powders } \\
\hline & & EPO-1 & EPO-2 & EPO-3 & EPO-4 \\
\hline \multicolumn{6}{|l|}{ Pigments' absorption } \\
\hline Chlorophylls (-) & $0.24 \pm 0.01 \mathrm{c}$ & $0.212 \pm 0.004 b$ & $0.208 \pm 0.007 b$ & $0.175 \pm 0.005 \mathrm{a}$ & $0.21 \pm 0.02 b$ \\
\hline Decrease $^{\mathrm{a}}(\%)$ & - & 13.1 & 14.8 & 28.3 & 14.6 \\
\hline Carotenoids (-) & $1.18 \pm 0.02 b$ & $0.98 \pm 0.05 \mathrm{a}$ & $0.93 \pm 0.02 \mathrm{a}$ & $0.99 \pm 0.08 \mathrm{a}$ & $0.97 \pm 0.01 \mathrm{a}$ \\
\hline Decrease $^{\mathrm{a}}(\%)$ & - & 17.3 & 21.5 & 16.5 & 18.3 \\
\hline \multicolumn{6}{|l|}{ Color } \\
\hline Total value (-) & $1428 \pm 5 b$ & $1192 \pm 45 \mathrm{a}$ & $1137 \pm 31 \mathrm{a}$ & $1164 \pm 66 a$ & $1176 \pm 2 \mathrm{a}$ \\
\hline Decrease $^{\mathrm{a}}(\%)$ & - & 16.6 & 20.4 & 18.5 & 17.7 \\
\hline \multicolumn{6}{|l|}{ Oxidative stability } \\
\hline OSI (h) & $6.1 \pm 0.2 \mathrm{a}$ & $6.0 \pm 0.4 \mathrm{a}$ & $5.1 \pm 0.1 \mathrm{a}$ & $6.2 \pm 0.7 \mathrm{a}$ & $2.1 \pm 0.1 \mathrm{~b}$ \\
\hline
\end{tabular}

${ }^{a}$ Decrease compared to the control sample

28 and $16-21 \%$, respectively. The greatest change in the absorption of chlorophyll pigments was found for oil encapsulated by spray-drying at $130^{\circ} \mathrm{C}$ from the homogenized emulsion. In contrast, the greatest decrease in carotenoid absorption was observed upon the spray-drying at the same temperature of the emulsion without pretreatment. Losses of pigments caused the brightening of pumpkin seed oil, but these changes were comparable for all encapsulated oils (total color values decreased by 17-20\%). A negative effect of air and temperature on the content of pigments in dried material was confirmed by other researches, e.g., Durante et al. (2014) and Tonon et al. (2008).

\section{Oxidative Stability of Encapsulated Pumpkin Seed Oil}

Results of the Rancimat test are shown in Table 5. The stability of control pumpkin seed oil expressed as the oxidation induction time was $6.1 \mathrm{~h}$. Some discrepancies occur in literature data regarding the oxidative stability of pumpkin seed oil. For example, Gorjanović et al. (2011) found that the induction time of oil obtained from seeds of hulless pumpkin ranged from $4.0 \mathrm{~h}$ (species C. pepo, cultivar Olianka) to $4.5 \mathrm{~h}$ (species C. pepo, cultivar Gleisdorfer Diamant). In turn, Rezig et al. (2012) reported that the oxidative stability of oil pressed from seeds of C. maxima reached $18.61 \mathrm{~h}$. Noteworthy is, however, the fact that Gorjanovic et al. (2011) were oxidizing the sample at a temperature of $100{ }^{\circ} \mathrm{C}$, Rezig et al. (2012) at a temperature of $120^{\circ} \mathrm{C}$. The process of oil encapsulation with the method of spray-drying, regardless of its parameters, had a negligible effect upon the OSI value. Homogenization of the emulsion before its drying also did not cause a decrease in the oxidative stability of the resultant powder (EPO-3). Horn et al. (2013) observed that the effect of homogenization temperature and pressure in emulsion prepared with whey protein was not clear, but the tendency was towards a more pronounced effect of pressure than of temperature. Thus, a higher pressure led to a lower peroxide value, but also to a higher concentration of volatile secondary oxidation products. In addition, these authors also reported that a low peroxide value and a high concentration of volatiles could result from fast degradation of lipid hydroperoxides in this emulsion, caused by exposure to transition metal ions. In turn, the pumpkin seed oil encapsulated by freeze-drying was subject to significant oxidation. The OSI value determined for that sample reached barely $2.1 \mathrm{~h}$ and was ca. threefold lower compared to the control sample. It could be explained by the morphology of EPO-4 powder, which is irregular in structure, highly porous, and has a large surface area (Fig. 2) which is exposed to a direct contact with oxygen. Hence, oxidation occurs early and rapidly, which is reflected in the values of oxidation parameters that reach their maxima as soon as after the first week of storage. It is consistent with results obtained by Velasco et al. (2009). Based on its microstructure, EPO-4 can facilitate diffusion of oxygen from the air onto the particle surface, which gets into the inner part of the particle due to the amorphous state of the matrix. Because of this accessibility, oxygen can easily decompose lipids that are not protected by matrices and those on the particle surface (Anwar and Kunz 2011). The relationship between food microstructure and oxidative stability was also underlined by Czaplicki et al. (2012), who studied the oxidative stability of amaranth products. In their study, oxidative changes occurring in popping were characterized by a considerably more rapid course compared to seeds and flakes. The peroxide value noted after 4 months of storage accounted for $0.43 \mathrm{mEq} \mathrm{O} / 2 / \mathrm{kg}$ in seeds, for $10 \mathrm{mEq} \mathrm{O}_{2} / \mathrm{kg}$ in flakes, and for as much as $130 \mathrm{mEq} \mathrm{O} / 2 \mathrm{~kg}$ in popping. It is indicative of the high susceptibility of extruded amaranth seeds to oxidation, which is mainly due to the porous structure of popping and to the use of high pressures and high temperatures during its production. 
In the presented study, we also demonstrated no influence of surface oil content on the stability of encapsulated pumpkin seed oil. It is in agreement with the work of Klinkersorn et al. (2005) who studied stability of spray-dried tuna oils.

\section{Conclusions}

Among four process conditions (spry-drying using two different inlet temperatures: $130{ }^{\circ} \mathrm{C}$ with or without homogenization of emulsion and $180^{\circ} \mathrm{C}$ without homogenization of emulsion, and freeze-drying with homogenization of emulsion), the spray-drying at the inlet temperature of $130{ }^{\circ} \mathrm{C}$ without homogenization of emulsion ensured the best results of encapsulation efficiency. The samples homogenized before spraydrying as well as freeze-drying had the lowest moisture content, which is an important feature for the applicability of powdered materials.

In the present study, we also demonstrated that low oxidation stability of powdered oil cannot solely be explained by the amount of surface oil. In analyzed samples, the content of surface oil was on the same level but the lowest stability was observed for the sample obtained by freeze-drying. It can be related with the highest degradation of tocopherols in this sample which protects oil against oxidation. On the other hand, in the freezedried sample, we observed the low degradation of sterols, which have a relevant importance from a nutritional point of view.

It was observed that as the inlet temperature increased in the spry-drying process, the bulk density of encapsulated oil decreased; however, the higher inlet temperature generated more free oil. We also found that capsules obtained at the lower inlet temperature were greater in size but the homogenization of emulsion reduced the size of particles. Moreover, capsules obtained at the inlet drying temperature of $130{ }^{\circ} \mathrm{C}$ were more deformed than those obtained at higher temperature.

Acknowledgments The authors would like to thank Adam Zinkiewicz, M.Sc., from the Chair of Plant Material Processing and Chemistry of the University of Warmia and Mazury in Olsztyn for his assistance in the freeze-drying of pumpkin seed oil emulsion.

Open Access This article is distributed under the terms of the Creative Commons Attribution 4.0 International License (http:// creativecommons.org/licenses/by/4.0/), which permits unrestricted use, distribution, and reproduction in any medium, provided you give appropriate credit to the original author(s) and the source, provide a link to the Creative Commons license, and indicate if changes were made.

\section{References}

Aghbashlo, M., Mobil, H., Madadlou, A., \& Rafiee, S. (2013). Influence of wall material and inlet drying air temperature on the microencapsulation of fish oil by spray drying. Food and Bioprocess Technology, 6(6), 1561-1569.
Anwar, S. H., \& Kunz, B. (2011). The influence of drying methods on the stabilization of fish oil microcapsules: comparison of spray granulation, spray drying, and freeze drying. Journal of Food Engineering, 105(2), 367-378.

AOAC. (1995). Association of Official Analytical Chemists, Official methods of analysis (Vol. I, 16th ed.). Gaithersburg, MD: AOAC method number 990.20; 33.2.44.

Augustin, M. A., \& Sanguansri, L. (2008). Encapsulation of bioactives. In J. M. Aguilera \& P. J. Lillford (Eds.), Food material science, principles and practice (pp. 577-601). New York: Springer.

Banville, C., Vuillemard, J. C., \& Lacroix, C. (2000). Comparison of different methods for fortifying cheddar cheese with vitamin D. International Dairy Journal, 10(5-6), 375-382.

Barriuso, B., Otaegui-Arrazola, A., Menéndez-Carreño, M., Astiasarán, A., \& Ansorena, D. (2012). Sterols heating: degradation and formation of their ring-structure polar oxidation products. Food Chemistry, 135(2), 706-712.

Barrow, C. J., Nolan, C., \& Holub, B. J. (2009). Bioequivalence of encapsulated and microencapsulated fish-oil supplementation. Journal of Functional Foods, 1(1), 38-43.

Beutner, S., Bloedorn, B., Frixel, S., Hernandez Blanco, I., Hoffmann, T., Martin, H.-D., Mayer, B., Noack, P., Ruck, C., Schmidt, M., Schülke, I., Sell, S., Ernst, H., Haremza, S., Seybold, G., Sies, H., Stahl, W., \& Walsh, R. (2001). Quantitative assessment of antioxidant properties of natural colorants and phytochemicals: carotenoids, flavonoids, phenols and idigoids. The role of $\beta$-carotene in antioxidant functions. Journal of the Science of Food and Agriculture, 81(6), 559-568.

Bruscatto, M. H., Zambiazi, R. C., Sganzerla, M., Pestana, V. R., Otero, D., Lima, R., \& Paiva, F. (2009). Degradation of tocopherols in rice bran oil submitted to heating at different temperatures. Journal of Chromatographic Science, 47(9), 762-765.

Calvo, P., Castaño, Á. L., Hernández, M. T., \& González-Gómez, D. (2011). Effects of microcapsule constitution on the quality of microencapsulated walnut oil. European Journal of Lipid Science and Technology, 113(10), 1273-1280.

Calvo, P., Castaño, Á. L., Lozano, M., \& Gonźalez-Gómez, D. (2012). Influence of the microencapsulation on the quality parameters and shelf-life of extra-virgin olive oil encapsulated in the presence of BHT and different capsule wall components. Food Research International, 45(1), 256-261.

Caparino, O. A., Tang, J., Nindo, C. I., Sablani, S. S., Powers, J. R., \& Fellman, J. K. (2012). Effect of drying methods on the physical properties and microstructures of mango (Philippine 'Carabao' var.) powder. Journal of Food Engineering, 111(1), 135-148.

Carneiro, H. C. F., Tonon, R. V., Grosso, C. R. F., \& Hubinger, M. D. (2013). Encapsulation efficiency and oxidative stability of flaxseed oil microencapsulated by spray drying using different combinations of wall materials. Journal of Food Engineering, 115(4), 443-451.

Celli, G. B., Ghanem, A., \& Brooks, M. S.-L. (2015). Bioactive encapsulated powders for functional foods - a review of methods and current limitations. Food Bioprocess and Technology, 8(9), 18251837.

Chegini, G. R., \& Ghobadian, B. (2005). Effect of spray-drying conditions on physical properties of orange juice powder. Drying Technology, 23(3), 657-668.

Chen, Q., McGillivray, D., Wen, J., Zhong, F., \& Quek, S. Y. (2013). Coencapsulation of fish oil with phytosterol esters and limonene by milk proteins. Journal of Food Engineering, 117(4), 505-512.

Choe, E., \& Min, D. B. (2007). Chemistry of deep-fat frying oils. Journal of Food Science, 72(5), 77-86.

Czaplicki, S., Ogrodowska, D., \& Zadernowski, R. (2012). Squalene and fatty acids in stored amaranthus products. Bromatology and Toxicology Chemistry, 45(3), 1141-1147 (in polish).

Czaplicki, S., Ogrodowska, D., Derewiaka, D., Tańska, M., \& Zadernowski, R. (2011). Bioactive compounds in unsaponifiable 
fraction of oils from unconventional sources. European Journal of Lipid Science and Technology, 113(12), 1456-1464.

Dos Santos, M. A. Z., Alicieo, T. V. R., Pereira, C. M. P., Ramis-Ramos, G., \& Mendonça, C. R. B. (2014). Profile of bioactive compounds in avocado pulp oil: Influence of the drying processes and extraction methods. Journal of the American Oil Chemists' Society, 91(1), 1927.

Drusch, S., \& Berg, S. (2008). Extractable oil in microcapsules prepared by spray-drying: localization, determination and impact on oxidative stability. Food Chemistry, 109(1), 17-24.

Drusch, S., \& Mannino, S. (2009). Patent-based review on industrial approaches for the microencapsulation of oils rich in polyunsaturated fatty acids. Trends in Food Science \& Technology, 20(6-7), 237244.

Durante, M., Lenucci, M., D’Amico, L., Piro, G., \& Mita, G. (2014). Effect of drying and co-matrix addition on the yield and quality of supercritical CO2 extracted pumpkin (Cucurbita moschata Duch.) oil. Food Chemistry, 148, 314-320.

Folch, J., Lees, M., \& Sloane Stanley, G. H. (1957). A simple method for the isolation and purification of total lipides from animal tissues. Journal of Biological Chemistry, 226(1), 497-509.

Fruhwirth, G. O., Wenzyl, T., El-Toukhy, R., Wagner, F. S., \& Hermetter, A. (2003). Flourescence screening of antioxidant capacity in pumpkin seed oils and other natural oils. European Journal of Lipid Science and Technology, 105(6), 266-274.

Gorjanović, S. Ž., Rabrenović, B. B., Novaković, M. M., Dimić, E. B., Basić, Z. N., \& Sužnjević, D. Ž. (2011). Cold-pressed pumpkin seed oil antioxidant activity as determined by a DC polarographic assay based on hydrogen peroxide scavenge. Journal of the American Oil Chemists' Society, 88(12), 1875-1882.

Górnaś, P., Siger, A., Juhṇeviča, K., Lācis, G., Šnē, E., \& Seglina, D. (2014). Cold-pressed Japanese (Chaenomeles japonica (Thunb.) Lindl. ex Spach) seed oil as rich source of $\alpha$-tocopherol, carotenoids and phenolics: a comparison of the composition and antioxidant activity with nine other plant oils. European Journal of Lipid Science and Technology, 116(5), 563-570.

Hogan, S. A., McNamee, B. F., O’Riordan, E. D., \& O’Sullivan, M. O. (2001). Microencapsulating properties of whey protein concentrate 75. Journal of Food Science, 66(5), 675-680.

Horn, A. F., Barouh, N., Nielsen, N. S., Baron, C. P., \& Jacobsen, C. H. (2013). Homogenization pressure and temperature affect protein partitioning and oxidative stability of emulsion. Journal of the American Oil Chemists' Society, 90(10), 1541-1550.

Iafelice, G., Caboni, M. F., Cubadda, R., Criscio, T., Trivisonno, M. C., \& Marconi, E. (2008). Development of functional spaghetti enriched with long chain omega-3 fatty acids. Cereal Chemistry, 85(2), 146151

Ixtaina, V. Y., Julio, L. M., Wagner, J. R., Nolasco, S. M., \& Tomás, M. C. (2015). Physicochemical characterization and stability of chia oil microencapsulated with sodium caseinate and lactose by spray-drying. Powder Technology, 271, 26-34.

Josquin, N. M., Linssen, J. P. H., \& Houben, J. H. (2012). Quality characteristics of Dutch-style fermented sausage manufactured with partial replacement of pork-fat with pure, pre-emulsified or encapsulated fish oil. Meat Science, 90(1), 81-86.

Jones, J. R., Prime, D., Leaper, M. C., Richardson, D. J., Rielly, C. D., \& Stapley, A. G. F. (2013). Effect of processing variables and bulk composition on the surface composition of spray dried powders of a model food system. Journal of Food Engineering, 118(1), 19-30.

Karaca, A. C., Nickerson, M., \& Low, N. H. (2013). Microcapsule production employing chickpea or lentil protein isolates and maltodextrin: physicochemical properties and oxidative protein of encapsulated flaxseed oil. Food Chemistry, 139(1-4), 448-457.

Kelly, G. M., O’Mahony, J. A., Kelly, A. L., \& O’Callaghan, D. J. (2014). Physical characteristics of spray-dried dairy powders containing different vegetable oils. Journal of Food Engineering, 122, 122-129.
Klinkersorn, U., Sophanodora, P., Chinachochoti, P., McClements, D. J., $\&$ Decker, E. A. (2005). Stability of spray-dried tuna oil emulsions encapsulated with two-layered interfacial membranes. Journal of Agricultural and Food Chemistry, 53(21), 8365-8371.

Lee, K. H., Jung, M. Y., \& Kim, S. Y. (1997). Quenching mechanism and kinetics of ascorbyl palmitate for the reduction of the photosensitized oxidation of oils. Journal of the American Oil Chemists' Society, 74(9), 1053-1057.

Liu, S., Low, N. H., \& Nickerson, M. T. (2010). Entrapment of flaxseed oil within gelatin-gum Arabic capsules. Journal of the American Oil Chemists' Society, 87(7), 809-815.

Najafi, M. N., Kadkhodaee, R., \& Mortazavi, S. A. (2011). Effect of drying process and wall material on the properties of encapsulated cardamom oil. Food Biophysics, 6(1), 68-76.

Nawirska-Olszańska, A., Kita, A., Biesiada, A., Sokół-Łętowska, A., \& Kucharska, A. Z. (2013). Characteristics of antioxidant activity and composition of pumpkin seed oil in 12 cultivars. Food Chemistry, 139(1-4), 155-161.

Neđeral, S., Petrović, M., Vincek, D., Pukec, D., Škevin, D., Kraljić, K., \& Obranović, M. (2014). Variance of quality parameters and fatty composition in pumpkin seed oil during three crop seasons. Industrial Crops and Products, 60, 15-21.

Nedovic, V., Kalusevic, A., Manojlovic, V., Levic, S., \& Bugarski, B. (2011). An overview of encapsulation technologies for food applications. Procedia Food Science, 1(2011), 1806-1815.

Obara, A., Obiedziński, M., \& Kołczak, T. (2006). The effect of water activity on cholesterol oxidation in spray- and freeze-dried egg powders. Food Chemistry, 95(2), 173-179.

Ogrodowska, D., Zadernowski, R., Czaplicki, S., Derewiaka, D., \& Wronowska, B. (2014). Amaranth seeds and products - the source of bioactive compounds. Polish Journal of Food and Nutrition Sciences, 64(3), 165-170.

Polish Standard (PN-A-86934:1995P) (1995). Oils and fats vegetable and animal. Determination of the general spectrophotometric colour. Polish Committee for Standardization (in Polish).

Pourashouri, P., Shabanpour, B., Razavi, S. H., Jafari, S. M., Shabani, A., \& Aubourg, S. P. (2014). Impact of wall materials on physicochemical properties of microencapsulated fish oil by spray drying. Food and Bioprocess Technology, 7(8), 2354-2365.

Procida, G., Stancher, B., Cateni, F., \& Zacchigna, M. (2013). Chemical composition and functional characterisation of commercial pumpkin seed oil. Journal of the Science of Food and Agriculture, 93(5), 1035-1041.

Quispe-Condori, S., Saldaña, M. D., \& Temelli, F. (2011). Microencapsulation of flax oil with zein using spray and freeze drying. LWT-Food Science and Technology, 44(9), 1880-1887.

Rabrenović, B. B., Dimić, E. B., Novaković, M. M., Tešević, V. V., \& Basić, Z. N. (2014). The most important bioactive components of cold pressed oil from different pumpkin (Cucurbita pepo L.) seeds. LWT-Food Science and Technology, 55(2), 521-527.

Reddy, L. H., \& Couvreur, P. (2009). Squalene: a natural triterpene for use in disease management and therapy. Advanced Drug Delivery Reviews, 61(15), 1412-1426.

Rezig, L., Chouaibia, M., Msaadab, K., \& Hamdia, S. (2012). Chemical composition and profile characterisation of pumpkin (Cucurbita maxima) seed oil. Industrial Crops and Products, 37(1), 82-87.

Rodea-González, D. A., Cruz-Olivares, J., Román-Guerrero, A., Rodríguez-Huezo, M. E., Vernon-Carter, E. J., \& Pérez-Alonso, C. (2012). Spray-dried encapsulation of chia essential oil (Salvia hispanica L.) in whey protein concentrate-polysaccharide matrices. Journal of Food Engineering, 111(1), 102-109.

Roszkowska, B., Tańska, M., Czaplicki, S., \& Konopka, I. (2015). Variation in the composition and oxidative stability of commercial rapeseed oils during their shelf life. European Journal of Lipid Science and Technology, 117(5), 673-683. 
Ruiz, J. C., Ortiz Vazquez, E. L., \& Campos, M. R. S. (2015). Encapsulation of vegetable oils as source of omega-3 fatty acids for enriched functional foods. Critical Reviews in Food Science and Nutrition, 57(7), 1423-1434.

Ryan, E., Chopra, J., McCarthy, F., Maguire, A. R., \& O’Brien, N. M. (2005). Qualitative and quantitative comparison of the cytotoxic and apoptotic potential of phytosterol oxidation products with their corresponding cholesterol oxidation products. British Journal of Nutrition, 94(3), 443-451.

Serfert, Y., Drusch, S., \& Schwarz, K. (2009). Chemical stabilisation of oils rich in long-chain polyunsaturated fatty acids during homogenisation, microencapsulation and storage. Food Chemistry, 113(4), 1106-1112.

Sharma, A., Jana, A. H., \& Chavan, R. S. (2012). Functionality of milk powders and milk-based powders for end use applications - a review. Comprehensive Reviews in Food Science and Food Safety, 11(5), 518-528.

Sharma, M., Kadam, D. M., Chadha, S., Wilson, R. A., \& Gupta, R. K. (2013). Influence of particle size on physical and sensory attributes of mango pulp powder. International Agrophysics, 27(3), 323-328.

Soupas, L., Huikko, L., Lampi, A. M., \& Piironrn, V. (2006). Oxidative stability of phytosterols in some food applications. European Food Research and Technology, 222(3), 266-273.

Spada, J. C., Noreña, C. P. Z., Marczak, L. D. F., \& Tessaro, I. C. (2012). Study on the stability of $\beta$-carotene microencapsulated with pinhão (Araucaria angustifolia seeds) starch. Carbohydrate Polymers, 89(1), 1166-1173.

Sun-Waterhouse, D., Zhou, J., Miskelly, G. M., Wibisono, R., \& Wadhawa, S. S. (2011). Stability of encapsulated olive oil in the presence of caffeic acid. Food Chemistry, 126(3), 1049-1056.

Tańska, M., Rotkiewicz, D., Kozirok, W., \& Konopka, I. (2005). Measurement of the geometrical features and surface colour of rapeseeds using digital image analysis. Food Research International, 38(7), 741-750.

Tonon, R. V., Brabet, C., \& Hubinger, M. D. (2008). Influence of process conditions in the physicochemical properties of açai (Euterpe oleracea Mart.) powder produced by spray drying. Journal of Food Engineering, 88(3), 411-518.

Tonon, R. V., Grosso, C. R. F., \& Hubinger, M. D. (2011). Influence of emulsion composition and inlet air temperature on the microencapsulation of flaxseed oil by spray drying. Food Research International, 44(1), 282-289.

Velasco, J., Holgado, F., Dobarganes, C., \& Márquez-Ruiz, G. (2009). Influence of relative humidity on oxidation of the free and encapsulated oil fractions in freeze-dried microencapsulated oils. Food Research International, 42(10), 1492-1500.

Vujasinovic, V., Djilas, S., Dimic, E., Romanic, R., \& Takaci, A. (2010). Shelf life of cold-pressed pumpkin (Cucurbita pepo L.) seed oil obtained with a screw press. Journal of the American Oil Chemists' Society, 87(12), 1497-1505.

Wang, R., Tian, Z., \& Chen, L. (2011). A novel process for microencapsulation of fish oil with barley protein. Food Research International, 44(9), 2735-2741.

Westergaard, V. (2004). Spray drying. In V. Westergaard (Ed.), Milk powder technology: evaporation and spray drying, (5th ed.) (pp. 71122). Copenhagen: GEA Niro A/S.

Zadernowski, R., \& Sosulski, F. (1978). Composition of total lipids in rapeseed. Journal of the American Oil Chemists' Society, 55(12), 870-872.

Zimmermann, M. B., Wegmueller, R., Zeder, C., Chaouki, N., Biebinger, R., Hurrell, R. F., \& Windhab, E. (2004). Triple fortification of salt with microcapsules of iodine, iron, and vitamin a. The American Journal of Clinical Nutrition, 80(5), 1283-1290. 